\title{
EFFECT OF SELECTED PLANT PREPARATIONS CONTAINING BIOLOGICALLY ACTIVE COMPOUNDS ON WINTER RAPE (BRASSICA NAPUS L.) YIELDING
}

\author{
Gugala, M. ${ }^{1}$ - SiKorska, A. ${ }^{2 *}$ - Findura, P. ${ }^{3,5}$ - KaPEla, K. ${ }^{4}$ - MAlaga-Tobola, U. ${ }^{5}-$ \\ ZARZECKA, K. ${ }^{1}-$ DOMANSKI, L. ${ }^{1}$ \\ ${ }^{1}$ Department of Agrotechnology, Siedlce University of Natural Sciences and Humanities \\ ul. Prusa 14, 08-110 Siedlce, Poland \\ (e-mail: gugala@uph.edu.pl) \\ ${ }^{2}$ Department of Agriculture, State Higher Vocational School in Ciechanów \\ ul. Narutowicza 9, 06-400 Ciechanów, Poland \\ (e-mail: anna.sikorska@pwszciechanow.edu.pl) \\ ${ }^{3}$ Department of Biosystems Engineering; Slovak University of Agriculture Nitra \\ Tr. A. Hlinku 2, 94976 Nitra, Slovak Republic \\ (e-mail: pavol.findura@uniag.sk)
}

${ }^{4}$ Department Agrometeorology and Agricultural Eingineering, Faculty of Natural Sciences, Siedlce University of Natural Sciences and Humanities, Prusa St. 14, 08-110 Siedlce, Poland (e-mail: krzysztof.kapela@uph.edu.pl)

${ }^{5}$ Faculty of Production and Power Engineering; University of Agriculture in Krakow ul. Balicka 116B; 30-149 Krakow, Poland

(e-mail: Urszula.Malaga-Tobola@ur.krakow.pl.)

*Corresponding author

e-mail: anna.sikorska@pwszciechanow.edu.pl

(Received $9^{\text {th }}$ Sep 2018; accepted $22^{\text {nd }}$ Nov 2018)

\begin{abstract}
A field experiment was carried out in 2013-2016 in the Agricultural Experimental Station Zawady of the University of Natural Sciences and Humanities in Siedlce, Poland. The examined factors included: I - three morphotypes of winter rape: population cultivar (Monolit), hybrid semi-dwarf (PR44D06) cultivar, restored hybrid cultivar of conventional growth type (PT205); II - two sowing methods: row spacing of $22.5 \mathrm{~cm}$, row spacing of $45.0 \mathrm{~cm}$; III - four types of applied biostimulators: control variant (without application of biostimulators), Tytanit ${ }^{\circledR}$ biostimulator, Asahi ${ }^{\circledR}$ SL biostimulator and Silvit ${ }^{\mathbb{B}}$ biostimulator. The aim of the research was to determine the effect of natural plant preparation on the yield of four cultivars of winter rape. It was found that biostimulators applied in the experiments increased the thousand-seed weight on average from 0.03 to $0.1 \mathrm{~g}$ in comparison to the control variant. The highest value of this feature was obtained in the variant with Asahi ${ }^{\circledR}$ SL treatment and significantly lower in plots treated with Silvit ${ }^{\circledR}$ and Tytanit ${ }^{\circledR}$ bioregulators. A significant increase in seed yielding was observed as the effect of natural growth stimulators. The highest value of this feature was observed in all cultivars after the application of Asahi ${ }^{\circledR} \mathrm{SL}$ and Silvit ${ }^{\circledR}$.
\end{abstract}

Keywords: Brassica napus, biostimulator, morphotype, seed yield, straw yield

\section{Introduction}

Unfavourable soil conditions and stress related to drought are one of numerous factors affecting a decrease in the quantity and quality of yield. Strong stress causes a disturbance of the cell structure and metabolism and, as a result, results in stopping the 
photosynthesis and disturbing plant metabolism. In the opinion of Sharm et al. (2014), the application of natural growth stimulators increases plant resistance to the unfavourable effects of various stress factors, including pathogens. Van Oosten et al. (2017) believe that biostimulators have a beneficial effect on the growth and productivity of plants, which is why they are gradually becoming elements of standard agrotechnics in the field cultivation. The composition of biostimulators usually include one or more biologically active organic compounds, such as: amino acids, vitamins, enzymes, plant hormones and macro and microelements, while a separate group consists of biopreparations produced with the participation of live microorganisms containing various types of bacteria and fungi.

Asahi SL, also known as Atonik or Chaperone, is the most often applied biostimulators in farming and horticulture. Asahi SL contains phenolic compounds: sodium o-nitrophenolate and sodium p-nitrophenolate and sodium 5-nitroguaiacolate, which naturally occur in plant cells and take part in biochemical and physiological plant processes. Phenols increase plant tolerance to all harmful stimuli from the environment, especially drought. Additionally, they reduce the decrease in auxins concentration in plants caused by water shortage, and control plant growth and development (Matysiak et al., 2011). Titanite is a mineral growth stimulant containing titanium ions that are organically complexed and are well absorbed by plants. Titanium is considered an essential element for the growth and development of plants. The application of even a small amount of titanium affects the growth of plants and increases their resistance to stress factors. It increases the activity of enzymes and thus increases the durability of mineral uptake in the soil.

Silvit is a natural growth stimulant containing the active silicon that is fully absorbed by plants. This bioregulator limits the physical penetration of tissues by pests, because cell walls become more resistant to enzymes produced by pathogens (fungistatic effect), increases plant tolerance to low temperatures, reduces transpiration during drought, intensifies photosynthesis in low light conditions, reduces the impact of high salinity for plant growth and phosphorus deficiency by regulating its uptake and eliminating toxic effects of aluminium on root growth.

The study assumed the research hypothesis that the application of natural plant preparations can contribute to an increase in winter rape (Brassica napus L.) yielding. Due to scarce research concerning the effect of this factor, a study was undertaken to determine the effect of the Tytanit ${ }^{\circledR}$, Asahi ${ }^{\circledR} \mathrm{SL}$ and Silvit ${ }^{\circledR}$ biostimulator on the thousand-seed weight, seed yield, straw yield and harvest index of three winter rape cultivars.

\section{Materials and Methods}

Field experiments were conducted in three growing seasons: I - from 13.08.2013 to 11.07.2014; II - 11.08.2014 to 17.07.2015; III - 14.08.2015 to 14.07.2016 in the Agricultural Experimental Station - Zawady $\left(52^{\circ} 03^{\prime} \mathrm{N}\right.$ and $\left.22^{\circ} 33^{\prime} \mathrm{E}\right)$ of the University of Natural Sciences and Humanities in Siedlce, Poland. The experiment was established at the random sub-blocks design (split - split - plot), in three replications. The surface of one plot for harvest was $18 \mathrm{~m}^{-2}$. It involved examination of the following factors: rape cultivars, sowing methods and types of biostimulators applied. With regard to the main experimental factor, three cultivars were sown, representing three cultivation types: population cultivar - Monolit, restored hybrid cultivar of a semi-dwarf growth type - 
PR44D06, restored hybrid cultivar of a conventional growth type - PT205. The secondary factor included two sowing methods: row spacing of $22.5 \mathrm{~cm}$ (row sowing density sowing of 60 seeds per $1 \mathrm{~m}^{-2}$ ), $45.0 \mathrm{~cm}$ planting space (precision sowing sowing density 40 seeds per $1 \mathrm{~m}^{-2}$ ). With regard to the tertiary factor, three types of biostimulators were applied against the control variant, cultivated without biostimulator application. Tytanit ${ }^{\circledR}$ biostimulator (active substance - titanium) was applied in autumn at the 4-8 leaves unfolded stage (BBCH 14-18) at the dose of $0.20 \mathrm{dm}^{3} \cdot \mathrm{ha}^{-1}$ (date I), in spring after vegetation started: beginning of side shoot development at the dose of 0.20 $\mathrm{dm}^{3} \cdot \mathrm{ha}^{-1}$ (date II), at the stage of flower bud development (inflorescence emergence) beginning of flowering at $0.20 \mathrm{dm}^{3} \cdot \mathrm{ha}^{-1}$ (date III). Asahi ${ }^{\circledR} \mathrm{SL}$ biostimulator was applied on three dates: in autumn at the BBCH 13-15 stage at the dose of $0.60 \mathrm{dm}^{3} \cdot \mathrm{ha}^{-1}$, in spring, after vegetation started at the dose of $0.60 \mathrm{dm}^{3} \cdot \mathrm{ha}^{-1}$, two weeks after performing the second procedure $\left(0.60 \mathrm{dm}^{3} \cdot \mathrm{ha}^{-1}\right)$. Silvit ${ }^{\circledR}$ biostimulators containing active silicon were applied three weeks after emergence at the dose of $0.20 \mathrm{dm}^{3} \cdot \mathrm{ha}^{-1}$, in spring, after vegetation started at the dose of $0.20 \mathrm{dm}^{3} \cdot \mathrm{ha}^{-1}$ and two weeks after the second procedure, at the dose of $0.20 \mathrm{dm}^{3} \cdot \mathrm{ha}^{-1}$.

The experiment was carried out on soil classified in the order of soils with clay translocation, type - Luvisols, subtype - Albic Luvisols. This soil was classified as IVa bonitation class soil, of very good rye complex for agricultural use. During the years of the experiment, soil $\mathrm{pH}$ (in $1 \mathrm{n} \mathrm{KCl}$ ) was slightly acidic, ranging from 5.68 to 5.75. The soil was characterized by a low total content of nitrogen (on average $0.85 \mathrm{~g} \cdot \mathrm{kg}^{-1}$ ), phosphorus (on average $0.44 \mathrm{~g} \cdot \mathrm{kg}^{-1}$ ), potassium (on average $0.65 \mathrm{~g} \cdot \mathrm{kg}^{-1}$ ) and calcium (on average $0.83 \mathrm{~g} \cdot \mathrm{kg}^{-1}$ ) and the medium content of magnesium (on average $0.42 \mathrm{~g} \cdot \mathrm{kg}^{-1}$ ) and sulphur (on average $0.13 \mathrm{~g} \cdot \mathrm{kg}^{-1}$ ). It demonstrated low content of available phosphorus forms (on average from 75 to $80 \mathrm{mg} \cdot \mathrm{kg}^{-1}$ ) and medium content of available forms of potassium (on average from 200 to $205 \mathrm{mg} \cdot \mathrm{kg}^{-1}$ ) and magnesium (on average from 59 to $\left.61 \mathrm{mg} \cdot \mathrm{kg}^{-1}\right)$. The forecrop for winter rape in the first year of research was spring wheat and in subsequent years it was winter triticale. After forecrop harvest, a set of post-harvest procedures was carried out using the ploughing aggregate + open cage roller, and then two weeks after the first procedure, pre-sow ploughing at the depth of $20.0 \mathrm{~cm}$ was carried out, using a ring roller at the same time. To prepare the soil for sowing and to mix fertilizers, a complex soil tillage unit was used. Before sowing, phosphorus-potassium fertilization was applied at the dose of $40 \mathrm{~kg} \mathrm{P} \cdot \mathrm{ha}^{-1}$ and $110 \mathrm{~kg}$ $\mathrm{K} \cdot \mathrm{ha}^{-1}$ and the first dose of $40 \mathrm{~kg} \mathrm{~N} \cdot \mathrm{ha}^{-1}$. Fertilization was applied in the form of Lubofos at the dose of $600 \mathrm{~kg}$. Fertilizing doses were supplemented with $55.9 \mathrm{~kg} \cdot \mathrm{ha}^{-1}$ of ammonium nitrate $\left(19 \mathrm{~kg} \mathrm{~N} \cdot \mathrm{ha}^{-1}\right), 29.6 \mathrm{~kg} \cdot \mathrm{ha}^{-1}$ triple superphosphate $\left(13.6 \mathrm{~kg} \mathrm{P} \cdot \mathrm{ha}^{-1}\right)$ and $29 \mathrm{~kg} \cdot \mathrm{ha}^{-1}$ potassium salt $\left(17.9 \mathrm{~kg} \mathrm{~K} \cdot \mathrm{ha}^{-1}\right)$. The second dose of nitrogen in the amount of $100 \mathrm{~kg} \cdot \mathrm{ha}^{-1}$ was applied in spring, before vegetation started (BBCH 28-30) applying ammonium nitrate at the dose of $255.5 \mathrm{~kg} \cdot \mathrm{ha}^{-1}\left(86.9 \mathrm{~kg} \mathrm{~N} \cdot \mathrm{ha}^{-1}\right)$ and ammonium sulphate at the dose of $62.5 \mathrm{~kg} \cdot \mathrm{ha}^{-1}$. The third dose of ammonium $60 \mathrm{~kg} \cdot \mathrm{ha}^{-1}$ was applied at the inflorescence emergence (BBCH 50), by applying ammonium nitrate at the dose of $176.5 \mathrm{~kg} \cdot \mathrm{ha}^{-1}\left(60 \mathrm{~kg} \mathrm{~N} \cdot \mathrm{ha}^{-1}\right)$. Winter rape was sown in two row spacing widths: $22.5 \mathrm{~cm}$ and $45.0 \mathrm{~cm}$, maintaining the density of 60 pieces $\cdot \mathrm{m}^{-2}$ and 40 pieces $\cdot \mathrm{m}^{-}$ ${ }^{2}$, respectively. The sowing was done at the optimal time recommended for this region (in 2013 - August 13, 2014 - August 11, and in 2015 - August 14). Directly after sowing, herbicide Command $480 \mathrm{EC}$ at the dose of $0.25 \mathrm{dm}^{3} \cdot \mathrm{ha}^{-1}$ was applied to carefully cultivated soil. Next, at the stage of BBCH 13-14, Fusilade Forte 150 EG at the dose of $2.0 \mathrm{dm}^{3} \cdot \mathrm{ha}^{-1}$ was applied. At the 4-8 leaves unfolded stage (BBCH 14-18) 
fungicide Horizon $250 \mathrm{EW}$ was applied $\left(0.75 \mathrm{dm}^{3} \cdot \mathrm{ha}^{-1}\right)$. At the stem elongation stage (BBCH 30), flower bud emergence stage (BBCH 50-58), flowering (BBCH 60-69) Proteus 110 OD insecticide was applied at the dose of $0.6 \mathrm{dm}^{3} \cdot \mathrm{ha}^{-1}$. At the beginning of flowering (BBCH 61) - Propulse 250 SE fungicide was applied at the dose of 1.0 $\mathrm{dm}^{3} \cdot \mathrm{ha}^{-1}$. At the stage of first petals falling - Mondatak $450 \mathrm{EC}$ was applied at the dose of $1.0 \mathrm{dm}^{3} \cdot \mathrm{ha}^{-1}$. Rape was collected in two stages, in the first and second decade of July (I year: 11.07.2014; II year: 17.07.2015; III year: 14.07.2016).

The thousand-seed weight was specified for two samples of 500 seeds, collected from purified yield from each plot. The volume of seed yield from each plot was determined by weight after threshing, and then, after adjusting to the normative humidity (9.0\% of water content in seeds), it was converted to the area of 1 ha.

The value of harvest index was calculated according to the formula:

$$
H I=\frac{P n}{P n+P s} * 100 \%
$$

where:

$\mathrm{HI}$ - harvest index $(\%)$

$\mathrm{Pn}-$ seed yield $\left(\mathrm{Mg} \cdot \mathrm{ha}^{-1}\right)$

Ps - straw yield $\left(\mathrm{Mg} \cdot \mathrm{ha}^{-1}\right)$.

The results of the study were statistically analysed with the use of the analysis of variance. The significance of variation sources was tested with the "F" FischerSnedecor test, and the assessment of significance at the significance level of $p=0.05$ between compared means - with Tukey's range test.

Weather conditions were diversified in the years of the research (Table 1).

Table 1. Characteristics of weather conditions in the years 2013-2016 (Zawady Meteorological Station, Poland)

\begin{tabular}{c|c|ccc|c|ccc}
\hline \multirow{2}{*}{ Months } & \multicolumn{4}{|c|}{ Rainfalls (mm) } & \multicolumn{3}{c}{ Air temperature $\left({ }^{\mathbf{O}} \mathbf{C}\right)$} \\
\cline { 2 - 9 } & $\begin{array}{c}\text { Multiyear } \\
\text { Sum }\end{array}$ & \multicolumn{3}{|c|}{ Monthly sum } & $\begin{array}{c}\text { Multiyear } \\
\text { mean }\end{array}$ & \multicolumn{3}{c}{ Monthly means } \\
\cline { 2 - 9 } & $\mathbf{1 9 9 6 - 2 0 1 0}$ & $\mathbf{2 0 1 3 -}$ & $\mathbf{2 0 1 4 -}$ & $\mathbf{2 0 1 5 -}$ & $\mathbf{1 9 9 6 - 2 0 1 0}$ & $\mathbf{2 0 1 3 -}$ & $\mathbf{2 0 1 4 -}$ & $\mathbf{2 0 1 5 -}$ \\
VIII & 59.9 & 15.0 & 105.7 & 11.9 & 18.5 & 18.8 & 18.1 & 21.0 \\
\cline { 2 - 9 } IX & 42.3 & 94.3 & 26.3 & 47.1 & 13.5 & 11.7 & 14.1 & 14.5 \\
X & 24.2 & 32.8 & 3.0 & 37.0 & 7.9 & 9.3 & 8.5 & 6.5 \\
XI & 20.2 & 34.7 & 32.5 & 42.2 & 4.0 & 5.1 & 3.4 & 4.7 \\
XII & 18.6 & 15.4 & 90.4 & 16.5 & -0.1 & 1.2 & 0.1 & 3.7 \\
I & 19.0 & 28.6 & 51.4 & 10.9 & -3.2 & -4.5 & 0.6 & -4.5 \\
II & 16.0 & 34.0 & 0.7 & 29.0 & -2.3 & 0.7 & 0.7 & 2.5 \\
III & 18.3 & 29.6 & 53.1 & 33.5 & 2.4 & 5.8 & 4.6 & 3.5 \\
IV & 33.6 & 45.0 & 30.0 & 28.7 & 8.0 & 9.8 & 8.2 & 9.1 \\
V & 58.3 & 92.7 & 100.2 & 54.8 & 13.5 & 13.5 & 12.3 & 15.1 \\
VI & 59.6 & 55.4 & 43.3 & 36.9 & 17.0 & 15.4 & 16.5 & 18.4 \\
VII & 57.5 & 10.0 & 62.6 & 35.2 & 19.7 & 20.8 & 18.7 & 19.1 \\
\hline VIII-VII & $\mathbf{4 2 7 . 5}$ & $\mathbf{4 8 7 . 5}$ & $\mathbf{5 9 9 . 2}$ & $\mathbf{3 8 3 . 7}$ & $\mathbf{8 . 2}$ & $\mathbf{9 . 0}$ & $\mathbf{8 . 8}$ & $\mathbf{9 . 5}$ \\
\hline
\end{tabular}


In the growing season 2013-2014 the total annual precipitation was by $60.0 \mathrm{~mm}$ higher in comparison to the average total precipitation from the multiannual period, and the mean air temperature was by $0.8^{\circ} \mathrm{C}$ higher. The highest annual total precipitation (on average $599.2 \mathrm{~mm}$ ) and the lowest mean annual air temperature (on average $8.8^{\circ} \mathrm{C}$ ) were recorded in the vegetation season of 2014-2015. The total annual precipitation in this period was higher by $171.7 \mathrm{~mm}$ in comparison with the total precipitation from the multiannual period. The 2015-2016 growing season was the warmest and most dry. The total annual precipitation was $43.8 \mathrm{~mm}$ lower than the multiannual average, and the average annual air temperature was $1.3^{\circ} \mathrm{C}$ higher in comparison to the mean of 19962010.

\section{Results and discussion}

The research demonstrated that Asahi SL, Silvit and Tytanit biostimulators significantly increased the thousand-seed weight on average from 0.03 to $0.1 \mathrm{~g}$ in comparison to the control variant (Table 2). The highest value of this feature was obtained in the variants where Asahi®SL was applied - on average $5.64 \mathrm{~g}$, and significantly lower in plots treated with Silvit ${ }^{\circledR}$ and Tytanit ${ }^{\circledR}$ bioregulators (on average $5.58 \mathrm{~g}$ and $5.57 \mathrm{~g}$ ). This is consistent with previous research by Harasimowicz-Hermann and Borowska (2006), who found that the thousand-seed weight was also higher by $18.0 \%$ in comparison to the control variant as a result of applying Asahi SL biostimulator.

Table 2. The weight of one thousand seeds ( $g$ ) depending on factors of experience

\begin{tabular}{|c|c|c|c|c|c|c|c|c|c|c|}
\hline \multirow{2}{*}{ Year } & \multicolumn{3}{|c|}{ Cultivars } & \multicolumn{2}{|c|}{$\begin{array}{l}\text { Ways of } \\
\text { sowing }\end{array}$} & \multicolumn{4}{|c|}{ Types of biostimulators used } & \multirow{2}{*}{ Mean } \\
\hline & $\begin{array}{l}2013- \\
2014\end{array}$ & $\begin{array}{l}2014- \\
2015\end{array}$ & $\begin{array}{l}2015- \\
2016 \\
\end{array}$ & 45.0 & 22.5 & $\begin{array}{l}\text { Control } \\
\text { variant }\end{array}$ & Tytanit ${ }^{\circledR}$ & Asahi ${ }^{\circledR S L}$ & Silvit ${ }^{\circledR}$ & \\
\hline Monolit & 5.47 & 5.33 & 5.51 & 5.46 & 5.41 & 5.39 & 5.42 & 5.51 & 5.42 & 5.43 \\
\hline $\begin{array}{c}\text { PR } \\
\text { 44D06 }\end{array}$ & 5.85 & 5.71 & 5.61 & 5.71 & 5.73 & 5.68 & 5.70 & 5.77 & 5.73 & 5.72 \\
\hline PT 205 & 5.72 & 5.60 & 5.48 & 5.60 & 5.60 & 5.55 & 5.59 & 5.65 & 5.60 & 5.60 \\
\hline Mean & 5.68 & 5.54 & 5.53 & 5.59 & 5.58 & 5.54 & 5.57 & 5.64 & 5.58 & - \\
\hline
\end{tabular}

$\mathrm{LSD}_{0.05}$ for: years - 0.01 ; cultivars - 0.01 ; types of biostimulators used - 0.02 ; ways of sowing - 0.01 interaction: years $\mathrm{x}$ cultivars -0.02 ; cultivars $\mathrm{x}$ types of biostimulators used -0.03 ; ways of sowing $\mathrm{x}$ cultivars - 0.02

On the other hand, Malarz et al. (2008) and Słowiński and Jarosz (2008) did not demonstrate a significant effect of biostimulators on thousand-seed weight. Matysiak et al. (2011) after the application of Asahi SL at the BBCH 28-30 stage obtained only a slight increase in thousand-seed weight and only in one research season, while Budzyński et al. (2008) after applying the same bioregulator, demonstrated only a trend towards an increase in the value of this feature. The thousand-seed weight of the semidwarf cultivar PR44D06 was on average higher by $0.12 \mathrm{~g}$ than for the conventional form PT 205, while the lowest (on average by $5.43 \mathrm{~g}$ ) was found for the line cultivar (Monolit). A similar trend was reported by Mekki (2013) and Czarnik et al. (2015). The authors obtained higher thousand-seed weights in heterotic cultivars than in population cultivars. On the other hand, Jankowski and Budziński (2007) recorded lower thousand- 
seed weight, on average by $8.0 \%$, in heterotic cultivars Kaszub and Kronos, as compared to population cultivar Contact. The thousand-seed weight was not significantly diversified in relation to the sowing method. The absence of a significant effect of this factor was also demonstrated by Ozera (2003), Shahin and Valiollah (2009), Uzun et al. (2012) and Krcek et al. (2014). On the other hand, Różyło and Pałys (2011) reported a slight trend to increase the thousand-seed weight for the $33.0 \mathrm{~cm}$ spacing in comparison to $25.0 \mathrm{~cm}$ spacing. The thousand-seed weight of the examined cultivars significantly depended on weather conditions in individual years of the experiment. Restored hybrids PR44D06 and PT205 demonstrated the highest thousandseed weight in the first year of the research, characterized by excessive precipitation in June and in the first decade of July, and lower values were obtained in the third year of research, with precipitation shortage occurring in May and June, and the average temperature in those months higher than the multiannual average. On the other hand, in that season, the population cultivar Monolit demonstrated the highest value of this feature in comparison to the initial years of the research. The types of applied biostimulators significantly affected the seed yield in the examined cultivars (Table 3).

Table 3. Seed yield $\left(\mathrm{Mg} \cdot \mathrm{ha^{-1 }}\right)$ depending on factors of experience

\begin{tabular}{|c|c|c|c|c|c|c|c|c|c|c|}
\hline \multirow{2}{*}{ Year } & \multicolumn{3}{|c|}{ Cultivars } & \multicolumn{2}{|c|}{$\begin{array}{l}\text { Ways of } \\
\text { sowing }\end{array}$} & \multicolumn{4}{|c|}{ Types of biostimulators used } & \multirow{2}{*}{ Mean } \\
\hline & $\begin{array}{l}\text { 2013- } \\
2014 \\
\end{array}$ & $\begin{array}{l}2014- \\
2015 \\
\end{array}$ & $\begin{array}{l}2015- \\
2016\end{array}$ & 45.0 & 22.5 & $\begin{array}{l}\text { Control } \\
\text { variant }\end{array}$ & Tytanit ${ }^{\circledR}$ & Asahi ${ }^{\circledR S L}$ & Silvit ${ }^{\circledR}$ & \\
\hline Monolit & 4.38 & 3.86 & 2.57 & 3.13 & 4.08 & 3.48 & 3.55 & 3.79 & 3.60 & 3.61 \\
\hline $\begin{array}{c}\text { PR } \\
\text { 44D06 }\end{array}$ & 4.93 & 4.45 & 2.74 & 3.66 & 4.42 & 3.84 & 3.99 & 4.24 & 4.09 & 4.04 \\
\hline PT 205 & 5.20 & 4.68 & 2.73 & 3.89 & 4.52 & 4.07 & 4.19 & 4.37 & 4.17 & 4.20 \\
\hline Mean & 4.84 & 4.33 & 2.68 & 3.56 & 4.34 & 3.80 & 3.91 & 4.13 & 3.96 & - \\
\hline
\end{tabular}

$\mathrm{LSD}_{0.05}$ for: years - 0.02 ; cultivars - 0.02 ; types of biostimulators used - 0.03 ; ways of sowing - 0.01 interaction: years $\mathrm{x}$ cultivars - 0.03 ; cultivars $\mathrm{x}$ types of biostimulators used - n.s.; ways of sowing $\mathrm{x}$ cultivars - n.s.

The highest value of this feature in all cultivars was observed after the application of Asahi ${ }^{\circledR} \mathrm{SL}$ - on average $4.13 \mathrm{Mg} \cdot \mathrm{ha}^{-1}$ and Silvit ${ }^{\circledR}$ - on average $3.96 \mathrm{Mg} \cdot$ ha- 1 . Similarly, Matysiak et al. $(2011,2012)$ found that Kelpak and Asahi SL bioregulators increased the volume of the seed yield on average by about $25 \%$. Harasimowicz-Hermann and Borowska (2006) depending on the vegetation season, found an increased yield in the range of 9.0 to $19.0 \%$ in comparison to the variant without natural growth stimulators. Budzyński et al. (2008) and Matysiak and Kaczmarek (2008) obtained the best yield producing effect in the variants where a single application was used at the $\mathrm{BBCH} 30$ stage or later $(\mathrm{BBCH} 50)$. The authors found that single application resulted in a yield increase on average by $3.0 \%(140 \mathrm{~kg}$ ), and double application (on average by $5.0 \%$ (220 $\mathrm{kg})$ ). The effect of the genetic factor on seed yield was demonstrated by Zhang et al. (2011), Mekki (2013) and Nowosad (2016). In own research, the highest seed yield (on average $4.20 \mathrm{Mg} \cdot \mathrm{ha}^{-1}$ ) was found for the long-stem cultivar PT205, significantly lower (on average $4.04 \mathrm{Mg} \cdot \mathrm{ha}^{-1}$ ) for PR44D06, and the lowest (on average $3.61 \mathrm{Mg} \cdot \mathrm{ha}^{-1}$ ) for the population cultivar Monolit. This is in line with the research results obtained by Jankowski and Budzyński (2007), El-Habbasha and El-Salama (2010) and Wójtowicz and Jajor (2010), who also emphasized that heterotic varieties demonstrated higher 
yielding potential than conventional ones. A higher seed yield in restored hybrid (DK Exquisite) of a conventional growth type was documented in Krcek et al. (2014). Jankowski et al. (2016) also recorded higher seed yields (on average $4.73 \mathrm{Mg} \cdot \mathrm{ha}^{-1}$ ) in the conventional morphotype of the Visby cultivar in comparison to semi-dwarf cultivars PR445D03 and Avenir. On the other hand, Kotecki et al. (2004) obtained the highest value of the analysed feature in the population morphotype (Lirajet and Lisek). The statistical calculations did not show any significant interaction between the varieties of biostimulators used. Increasing sowing density from 40 to 60 seeds per $1 \mathrm{~m}^{-2}$ significantly affected an increase in seed yield (on average by $0.78 \mathrm{Mg} \cdot \mathrm{ha}^{-1}$ ). No interaction was proven between cultivars and methods of sowing. This shows that similar cultivars responded in a similar way to row spacing and sowing density. Similar results were obtained by Cheema et al. (2001), Ozera (2003) and Champiri and Bagheri (2013). Those authors found a higher value of the discussed feature in narrow row spacing in comparison to cultivation at 30.0 and $45.0 \mathrm{~cm}$. This regularity was also confirmed by Uzun et al. (2012), Różydło and Pałys (2014) and Kutcher et al. (2015). Different research results were obtained by Krcek et al. (2014) who, based on one-year studies, did not reveal significant differences in the seed yield for narrow $(12.5 ; 25.0$ $\mathrm{cm})$ and wide $(35.0 ; 45.0 \mathrm{~cm})$ row spacing. The analysis of variance did not show any significant interaction of varieties with the sowing methods, which indicates that the studied varieties reacted in the same way to changing the inter-row spacing. Yana and Hunta (1998) provide that humidity and thermal conditions in $80 \%$ affect the yield. In own research, the highest precipitation in September at the level of $94.3 \mathrm{~mm}$, more than twice as high as the multiannual average, occurred in the first year of the research. In that season, characterized by an annual total precipitation at the level of 487.5 , the highest seed yield was recorded. Similar research results were obtained by Kotecki et al. (2004), who found the highest value of the analysed feature in the years of the total annual precipitation of $520 \mathrm{~mm}$. Our own research demonstrated that cultivars were characterized by varied seed yield in individual years of the research. In the season characterized by the highest average air temperature and the lowest total precipitation, significantly the highest value of the analysed feature was recorded in restored hybrid morphotypes. Gehringer et al. (2007) found that heterotic cultivars also demonstrated a higher ability to adapt to unfavourable weather conditions. The types of applied biostimulators significantly affected the straw yield and harvest index (Tables 4, 5). The highest values of those features were obtained in the variant treated with Asahi SL biostimulator (on average $6.41 \mathrm{Mg} \cdot \mathrm{ha}^{-1}$, on average $38.8 \%$ ). Other biostimulators increased the straw yield (on average by $0.10 \mathrm{Mg} \cdot \mathrm{ha}^{-1}$ ) in comparison to the control variant and harvest index (on average by $3.8 \%$ ). The straw yield of semi-dwarf cultivar PR44D06 was lower on average by about $4.0 \%$ in comparison to other winter rape cultivars. The by-product yield was not conditioned by weather conditions in the years of the experiment. The statistical calculations did not show any significant interaction of the studied varieties with the climatic conditions prevailing in the years of conducting the experiment, which means that varieties reacted in the same way to weather conditions in individual years of research. The seed yield to the biomass yield ratio (harvest index - HI) was more favourable in heterotic cultivars than in the population cultivar Monolit. Different results were obtained by Zając et al. (2013). Those authors statistically found insignificant differences between the population morphotype Poznaniak and the restored hybrid Adam. Our own research demonstrated that the byproduct yield of the analysed cultivars increased significantly along with an increase in 
sowing density. Statistical calculations did not show any significant interaction between the studied varieties and the sowing methods. Similarly, the harvest index assumed more favourable values in conditions of reduced row spacing. The highest by-product yield in the three-year research cycle (on average $7.19 \mathrm{Mg} \cdot \mathrm{ha}^{-1}$ ) was obtained in the vegetation period of 2014-2015, which was characterized by varied humidity and thermal conditions during the phase of plant growth and development, significantly lower - (on average $6.89 \mathrm{Mg} \cdot \mathrm{ha}^{-1}$ in 2013-2014) was characterized by optimum weather conditions during the vegetation season and winter rest and the lowest (on average 4.86 $\mathrm{Mg} \cdot \mathrm{ha}^{-1}$ ) was in 2015-2016, where significant frost damage to plants occurred and a precipitation shortage was recorded in April, May and June. In the first year of the research, characterized by average precipitation $(487.5 \mathrm{~mm})$, the highest value of harvest index was obtained and the lowest (on average 35.4\%) was obtained in the vegetation season of 2015-2016 with the significantly lowest precipitation $(383.7 \mathrm{~mm})$.

Table 4. Straw yield $\left(\mathrm{Mg} \cdot h \mathrm{~h}^{-1}\right)$ depending on factors of experience

\begin{tabular}{|c|c|c|c|c|c|c|c|c|c|c|}
\hline \multirow{2}{*}{ Year } & \multicolumn{3}{|c|}{ Cultivars } & \multicolumn{2}{|c|}{$\begin{array}{l}\text { Ways of } \\
\text { sowing }\end{array}$} & \multicolumn{4}{|c|}{ Types of biostimulators used } & \multirow{2}{*}{ Mean } \\
\hline & $\begin{array}{l}2013- \\
2014 \\
\end{array}$ & $\begin{array}{l}2014- \\
2015 \\
\end{array}$ & $\begin{array}{l}2015- \\
2016 \\
\end{array}$ & 45.0 & 22.5 & $\begin{array}{l}\text { Control } \\
\text { variant }\end{array}$ & Tytanit ${ }^{\circledR}$ & Asahi ${ }^{\circledR S L}$ & Silvit ${ }^{\circledR}$ & \\
\hline Monolit & 6.92 & 7.23 & 4.87 & 6.15 & 6.53 & 6.18 & 6.35 & 6.47 & 6.36 & 6.34 \\
\hline $\begin{array}{c}\text { PR } \\
\text { 44D06 }\end{array}$ & 6.75 & 7.04 & 4.74 & 6.09 & 6.25 & 6.15 & 6.17 & 6.23 & 6.14 & 6.17 \\
\hline PT 205 & 7.00 & 7.31 & 4.97 & 6.29 & 6.57 & 6.31 & 6.40 & 6.52 & 6.47 & 6.43 \\
\hline Mean & 6.89 & 7.19 & 4.86 & 6.18 & 6.45 & 6.21 & 6.31 & 6.41 & 6.32 & - \\
\hline
\end{tabular}

$\mathrm{LSD}_{0.05}$ for: years -0.03 ; years -0.03 ; types of biostimulators used -0.03 ; ways of sowing -0.02 interaction: years $\mathrm{x}$ cultivars $-\mathrm{n}$.s.; cultivars $\mathrm{x}$ types of biostimulators used -0.06 ; ways of sowing $\mathrm{x}$ cultivars - n.s.

Table 5. Harvesting index $(\mathrm{HI})(\%)$ depending on factors of experience

\begin{tabular}{|c|c|c|c|c|c|c|c|c|c|c|}
\hline \multirow{2}{*}{ Year } & \multicolumn{3}{|c|}{ Cultivars } & \multicolumn{2}{|c|}{$\begin{array}{l}\text { Ways of } \\
\text { sowing }\end{array}$} & \multicolumn{4}{|c|}{ Types of biostimulators used } & \multirow{2}{*}{ Mean } \\
\hline & $\begin{array}{l}2013- \\
2014 \\
\end{array}$ & $\begin{array}{l}2014- \\
2015 \\
\end{array}$ & $\begin{array}{l}2015- \\
2016 \\
\end{array}$ & 45.0 & 22.5 & $\begin{array}{l}\text { Control } \\
\text { variant }\end{array}$ & Tytanit ${ }^{\circledR}$ & Asahi ${ }^{\circledR S L}$ & Silvit ${ }^{\circledR}$ & \\
\hline Monolit & 37.6 & 35.7 & 34.3 & 33.4 & 38.3 & 35.6 & 35.5 & 36.6 & 35.8 & 35.9 \\
\hline $\begin{array}{c}\text { PR } \\
\text { 44D06 }\end{array}$ & 41.1 & 39.7 & 36.5 & 37.0 & 41.1 & 37.8 & 38.8 & 40.1 & 39.6 & 39.1 \\
\hline PT 205 & 41.5 & 40.0 & 35.4 & 37.6 & 40.3 & 38.6 & 39.0 & 39.6 & 38.6 & 39.0 \\
\hline Mean & 40.1 & 38.5 & 35.4 & 36.0 & 39.9 & 37.4 & 37.8 & 38.8 & 38.0 & - \\
\hline
\end{tabular}

$\mathrm{LSD}_{0.05}$ for: years - 0.1 ; years - 0.1 ; types of biostimulators used -0.2 ; ways of sowing - 0.1 interaction: years $\mathrm{x}$ cultivars $-\mathrm{n} . \mathrm{s}$; ; cultivars $\mathrm{x}$ types of biostimulators used -0.3 ; ways of sowing $\mathrm{x}$ cultivars -0.2

\section{Conclusions}

1. Biostimulators applied in the experiment had a significant effect on the thousandseed weight, the main yield, the by-product yield and the seed yield to biomass yield ratio (HI) of the examined winter rape morphotypes. The strongest stimulating effect was found after the application of Asahi SL biostimulator. 
2. The highest yielding was found for restored hybrids PT205 and PR44D06. It was demonstrated that their yield was on average 43 to $59 \mathrm{Mg} \cdot \mathrm{ha}^{-1}$ higher in comparison to the conventional cultivar.

3. In the examined winter rape morphotypes, under the effect of increased row spacing and decreased sowing density, a reduction of seed yield was found, on average from 0.63 to $0.95 \mathrm{Mg} \cdot \mathrm{ha}^{-1}$. The lowest main yield resulting from a factor change was demonstrated in the line cultivar Monolit.

4. Weather conditions in the year of the experiment had a significant effect on the value of the examined parameters. The highest seed yield was observed in the vegetation season of 2013-2014, characterized by the best pluvio-thermal conditions during the spring-summer development of winter rape.

Acknowledgements. The results of the research carried out under the research theme No. 363/S/13 were financed from the science grant granted by the Ministry of Science and Higher Education.

\section{REFERENCES}

[1] Budzyński, W., Dubis, W., Jankowski, K. (2008): Response of winter oilseed rape to the biostimulator Asahi SL applied in spring. - In: Dąbrowski, Z.T. (ed.) Biostimulators in Modern Agriculture. Field Crops: 18-25. Warsaw: Editorial House Wieś Jutra.

[2] Champiri, M., Bagheri, H. (2013): Yield and yield component canola cultivars (Brassica napus L.) under influence by planting densities in Iran Roya. - Intl. Res. J. Appl. Basic. Sci. 4(2): 353-355.

[3] Cheema, M. A., Saleem, M., Malik, M. A. (2001): Effect of row spacing and nitrogen management of agronomic traits and oil quality of canola (Brassica napus L.). - Pakistan Journal of Agricultural Sci. 38: 15-18.

[4] Czarnik, M., Jarecki, W., Bobrecka-Jamro, D., Jarecka A. (2015): The effects of sowing density and foliar feeding on yielding of winter oilseed rape Cultivars. - Rośliny OleisteOilseed Crops 36(1): 60-68. (in Polish).

[5] El-Habbasha, S. F., El-Salam, M. A. (2010): Response of two canola varieties (Brassica napus L.) to nitrogen fertilizer levels and zinc foliar application. - Int. J. Acad. Res. 2(2): 60-66.

[6] Gehringer, A., Snowdon, R., Spiller, T., Basunanda, P., Friedt, W. (2007): New oilseed rape (Brassica napus L.) hybrids with high levels of heterosis for seed yield under nutrient-poor conditions. - Breed Sci 57: 315-320.

[7] Harasimowicz-Hermann, G., Borowska, M. (2006): Effect of biostimulant Asahi SL in winter rapeseed depending on pluviothermic conditions. - Rośliny Oleiste-Oilseed Crops XXVII(1): 95-106.

[8] Jankowski, K. J., Budzyński, W. (2007): Reakcja różnych form hodowlanych rzepaku ozimego na termin i gęstość siewu I. Jesienny wzrost i rozwój oraz przezimowanie roślin. - Rośliny Oleiste-Oilseed Crops XXVIII (2): 177-194.

[9] Jankowski, K. J., Budzyński, W., Załuski, D., Hulanicki, P. S., Dubis B. (2016): Using a fractional factorial design to evaluate the effect of the intensity of agronomic practices on the yield of different winter oilseed rape morphotypes. - Field Crops Research 188: 5061.

[10] Kotecki, A., Kozak, M., Malarz, W. (2004): The effect of different crop production systems on growth and yielding of winter rape cultivars. - Rośliny Oleiste-Oilseed Crops XXV(1): 97-108. 
[11] Krcek, V., Baranyk, P., Pulkrabek, J., Urban, J., Skerikova, M., Brant, V., Zabransky, P. (2014): Influence of crop management on winter oilseed rape yield formation - evaluation of first year of experiment. - MendelNet: 59-63.

[12] Kutcher, H. R., Turkington, T. K., Clayton, G. W., Harker, K. N. (2013): Response of herbicide-tolerant canola (Brassica napus L.) cultivars to four row spacings and three seeding rates in a no-till production system. - Canadian Journal of Plant Sci. 93(6): 1229-1236. DOI: 10.4141/cjps2013-173.

[13] Malarz, W., Kozak, M., Kotecki, A. (2008): The use of Asahi SL biostimulator in spring rape growing. - In: Dąbrowski, Z.T. (ed.) Biostimulators in Modern Agriculture. Field Crops: 25-33. Warsaw: Editorial House Wieś Jutra.

[14] Matysiak, K., Kaczmarek, S. (2008): Potential advantages of Kelpak bioregulator applied to some field crops. - In: Dąbrowski, Z.T. (ed.) Biostimulators in Modern Agriculture. Field Crops: 99-106. Warsaw: Editorial House Wieś Jutra.

[15] Matysiak, K., Adamczewski, K., Kaczmarek, S. (2011): Response of some crops cultivated in Great Poland to application of Asahi SL. - Prog. Plant Prot./Post. Ochr. Roślin 51(4): 1849-1857. (in Polish).

[16] Matysiak, K., Kaczmarek, S., Kierzek, R. (2012): Effect of algae Ecklonia maxima (Kelpak SL) on winter oilseed rape. - Rośliny Oleiste-Oilseed Crops XXXIII(1): 81-88. (in Polish).

[17] Mekki, B. B. (2013): Yield and Quality Traits of Some Canola Varieties Grown in Newly Reclaimed Sandy Soils in Egypt. - World Applied Sciences Journal 25(2): 258-263. DOI: 10.5829/idosi.wasj.2013.25.02.13310.

[18] Nowosad, K., Liersch, A., Popławska, W., Bocianowski, J. (2016): Genotype by environment interaction for seed yield in rapeseed (Brassica napus L.) using additive main effects and multiplicative interaction model. - Euphytica 208(1): 187-194.

[19] Ozer, H. (2003): The effect of plant population densities on growth, yield and yield components of two spring rapeseed cultivars. - Plant, Soil and Environ. 49(9): 422-426.

[20] Różydło, K., Pałys, E. (2011): Yielding of winter rape grown on the rendzina soil as dependent on the rape share in crop rotation and the row spacing. - Zesz. Probl. Post. Nauk Rol. 599: 161-169. (in Polish).

[21] Różydło, K., Pałys, E. (2014): New oilseed rape (Brassica napus L.) varieties - canopy development, yield components, and plant density. - Acta Agriculturae Scandinavica, Sec. B - Soil \& Plant Science 64(3): 260-266. DOI:10.1080/09064710.2014.905625.

[22] Shahin, Y., Valiollah, R. (2009): Effects of row spacing and seeding rates on some agronomical traits of spring canola (Brassica napus L.) cultivars. - J. Cent. Eur. Agric 10(1): 115-122.

[23] Sharma, S. H. S., Fleming, C., Selby, Ch., Rao, J. R., Trevor, M. (2014): Plant biostimulants: a review on the processing of macroalgae and use of extracts for crop management to reduce abiotic and biotic stresses. - J. Appl. Phycol. 26: 465-490.

[24] Słowiński, A., Jarosz, A. (2008): Incorporating the Asahi SL biostimulator with the technology of winter rape cultivation. - Mat. Konf. 7-8 lutego 2008, Warszawa, 98. (in Polish).

[25] Uzun, B., Yol, E., Furat, S. (2012): The influence of row and intra-row spacing to seed yield and its components of winter sowing canola in the true Mediterranean type environment. - Bulg. J. Agric. Sci. 18: 83-91.

[26] Van Oosten, M. J., Pepe, O., De Pascale, S., Silletti, S., Maggio, A. (2017): The role of biostimulants and bioeffectors as alleviators of abiotic stress in crop plants. - Chem. Biol. Technol. Agric. 4(1): 1-12. doi: 10.1186/s40538-017- 0089-5.

[27] Wójtowicz, M., Jajor, E. (2010): Effect of some production technology factors on the yield of winter oilseed rape. - Prog. Plant Prot./Post. Ochr. Roślin 50(2): 565-569. (in Polish).

[28] Yan, W., Hunt, L. A. (1998): Genotype by environment interaction and crop yield. Plant Breed Rev 16: 135-178. 
[29] Zając, T., Kulig, B., Oleksy, A., Stok, A., Pyziak, K., Styrc, N. (2013): Development and yield of morphologically different groups of winter oilseed rape canopy II. the harvest index value depending on the cutting height. - Acta Sci. Pol., Agricultura 12(1): 57-64.

[30] Zhang, H. P., Berger, J. D., Milroy, S. (2011): Genotype x environment interaction of canola (Brassica napus L.) in multi-environment trials. - 17th Australian Research Assembly on Brassicas, Wagga Wagga, New South Wales, Australia. 